Article

\title{
Estimating the Potential for Conservation and Farming in the Amazon and Cerrado under Four Policy Scenarios
}

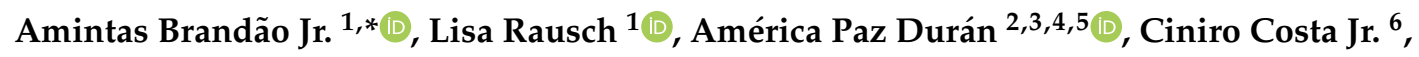 \\ Seth A. Spawn ${ }^{1,7}$ and Holly K. Gibbs ${ }^{1,7}$ \\ 1 Center for Sustainability and the Global Environment (SAGE), University of Wisconsin-Madison, \\ 1710 University Avenue, Madison, WI 53726, USA; llrausch@wisc.edu (L.R.); spawn@wisc.edu (S.A.S.); \\ hkgibbs@wisc.edu (H.K.G.) \\ 2 Conservation Science Group, Department of Zoology, University of Cambridge, Cambridge CB2 3QZ, UK; \\ paz.duran.moya@gmail.com \\ 3 UN Environment World Conservation Monitoring Center, Huntingdon Road, Cambridge CB3 0DL, UK \\ 4 Luc Hoffmann Institute, c/o WWF International, Avenue du Mont Blanc, 1196 Gland, Switzerland \\ 5 Instituto de Ciencias Ambientales y Evolutivas, Universidad Austral de Chile, Valdivia 5090000, Chile \\ 6 Instituto de Manejo e Certificação Florestal e Agrícola (Imaflora), 185 Estrada Chico Mendes, \\ Piracicaba, SP 13426 420, Brazil; ciniro@imaflora.org \\ 7 Department of Geography, University of Wisconsin-Madison, 550 North Park Street, \\ Madison, WI 53706, USA \\ * Correspondence: abrandao@wisc.edu; Tel.: +1-608-265-0572
}

Received: 19 December 2019; Accepted: 5 February 2020; Published: 10 February 2020

\begin{abstract}
Since 2013, clearing rates have rapidly increased in the Amazon and Cerrado biomes. This acceleration has raised questions about the efficacy of current regional public and private conservation policies that seek to promote agricultural production while conserving remnants of natural vegetation. In this study, we assessed conservation and agricultural outcomes of four potential policy scenarios that represent perfect adherence to private sector, zero-deforestation commitments (i.e., the Amazon soy moratorium-ASM and the Amazon cattle agreements-CA) and to varying levels of implementation of the Brazilian Forest Code (FC). Under a zero-clearing scenario, we find that the extent of croplands as of 2017 within the two biomes (31 MHa) could double without further clearing if agriculture were to expand on all previously cleared land that is suitable for crops. Moreover, at least $47 \mathrm{MHa}$ of land that is already cleared but unsuitable for crops would remain available for pasture. Under scenarios in which only legal clearing under the FC could occur, $51 \mathrm{MHa}$ of additional natural vegetation could be cleared. This includes as many as $1 \mathrm{MHa}$ of nonforest vegetation that could be cleared in the Amazon biome without triggering the ASM and CA monitoring systems. Two-thirds of the total vegetation vulnerable to legal clearing is located within the Cerrado biome, and $19 \mathrm{MHa}$ of this land is suitable for cropland expansion. Legal clearing of all of these areas could reduce biodiversity persistence by $4 \%$ within the two biomes, when compared with the zero-clearing scenario, and release up to $9 \mathrm{PgCO}_{2} \mathrm{e}$, with the majority $(75 \%)$ coming from the Cerrado biome. However, when we considered the potential outcomes of full implementation of the FC, we found that $22 \%$ (11 MHa) of the $51 \mathrm{MHa}$ of vegetation subject to legal clearing could be protected through the environmental quotas market, while an additional $1 \mathrm{MHa}$ should be replanted across the two biomes, predominantly in the Amazon biome (73\% of the area subject to replanting). Together, quotas and replanting could prevent the release of $2 \mathrm{PgCO}_{2} \mathrm{e}$ that would otherwise be emitted if all legal clearing occurred. Based on our results, we conclude that ongoing legal clearing could create additional space for cropland and cattle production beyond the substantial existing stocks of cleared areas but would significantly impair local carbon and biodiversity stocks.
\end{abstract}

Keywords: Brazil; Amazon; Cerrado; Forest Code; supply chain; soy moratorium; cattle agreements 


\section{Introduction}

The Amazon and Cerrado biomes are essential to agricultural production in Brazil, but they have different environmental policies in place to control land clearing. These two biomes comprise $70 \%$ of Brazil's land area and include much of the remaining native vegetation, more than $53 \%$ of the country's cattle herds, and $60 \%$ of grain production [1,2]. Concerns about the rapid loss of native vegetation from expansion of agribusiness (soy and cattle), led to the implementation of numerous public and private sector policies in the mid-2000s, including the 2004 plan to control illegal deforestation in the Amazon, the 2006 Amazon soy moratorium (ASM), and the 2009 zero-deforestation cattle agreements (CA) [3-7]. Together, these policies contributed to an 84\% decline in annual deforestation between 2004-2012 in the Amazon biome [6-8], though questions remain about the relative contribution of any one policy in attaining this reduction [9-11]. Although a deforestation control plan has covered the Cerrado biome since 2010, in general, the Cerrado is less protected overall than the Amazon. For example, the Brazilian Forest Code (FC) — the federal legislation that regulates land use on rural farms [10,12]—allows up to four times more clearing in the Cerrado than in the Amazon. Moreover, the Cerrado has less protected areas than the Amazon [13] and no ASM or CA supply chain initiatives [14].

While some studies suggest that these public policies were the primary drivers of reduced clearing in the Amazon [6-8,15-18], others have emphasized the role of zero-deforestation commitments made by members of the private sector $[5,19,20]$. However, since 2013 , clearing rates have again been rising in the Amazon [9], and pressure to further clear land may be spilling over into the Cerrado [21]. Concerns are also growing about the impacts of the ongoing agricultural conversion of the Cerrado - much of which is legal under the FC—on the water, climate, and livelihood cycles of the region [12,13,22-25]. As a result, high-profile negotiations with a particular focus on the soy and meat supply chains are underway to develop new policies and commitments to limit further clearing in the Cerrado [14].

Uncertainty over past policy outcomes for the Amazon region and ongoing efforts to improve protections in the Cerrado together raise essential questions about how best to reduce clearing. In this study, we contribute to that discussion by estimating the potential impact of zero-deforestation commitments, including the ASM and the CA, and of the FC on forests, cropland, and pastureland areas in these biomes. We consider the suitability of previously cleared land as well as of new areas that could be legally converted under the FC. We also identify how much land would be needed to attain full compliance with the FC. This would require that most farm owners do some degree of replanting or obtain off-farm reserves. Finally, we compare the implications that these policies have on carbon emissions and biodiversity. Answers to these questions may help us better understand the extent to which cropland and pastureland could be affected by these different policy approaches.

To answer these questions, we assessed four scenarios that represent varying levels of restrictions on new clearing. Our first scenario estimated the amount of land cleared as of 2017 that is suitable for crop and for pasture expansion, assuming no further clearing of any type of natural vegetation. In our second scenario, we estimated the maximum area that could be available for croplands and pasture, including the cleared land from the first scenario and the nonforest vegetation (e.g., savannas) that could be cleared legally under the FC, but without violating the ASM and the CA. Our third scenario estimated the maximum area that could be available for croplands and pasture if all vegetation of any type that could be legally cleared under the FC were to be cleared. Finally, our fourth scenario represents the full legal compliance with the FC, where we estimated, in addition to the areas of the third scenario, the vegetation "deficits"; that is, the cleared area that would either need to be replanted or compensated to meet FC requirements and which ultimately protects the vegetation surplus against the legal clearing. Within these scenarios, we first assumed no additional clearing of any type of vegetation, and then perfect compliance with the FC, the ASM, and the CA, to show their maximum potential impact, even though, in reality, landowners may not always fully comply with policies. 


\section{Background on the Three Policies Assessed by Our Scenarios}

Launched in 1934 [26], and subsequently updated in 1965 [27] and 2012 [28], the FC asks farmers to delineate the boundaries of their farms, as well as areas for "alternative land use" (areas that could be cropped or grazed) and conservation. Conservation areas are intended for environmental preservation and are further divided into areas of permanent protection (APP) and legal reserves (LR). In the case of APPs, which are generally delimited by river width and topographic characteristics, the objective is to protect the environmental functions of areas located along with water bodies and hilltops; thus, APPs do not allow for any economic activities and must always be replanted if cleared. LRs consist of the remaining vegetation that can be economically exploited by sustainable forest management practices (e.g., sustainable logging). They are delineated based on the size of the farm and its location relative to the Legal Amazon - a political entity that encompasses seven Brazilian States in their entirety and two in part. For all farms outside the Legal Amazon, the LR occupies 20\% of the farm area. While the entire Amazon biome is located within the Legal Amazon, most of the Cerrado biome (63\%) is outside of it. For farms within the Legal Amazon, three situations apply, depending on the type of vegetation that covers the farm: (i) if the farm has forests, the LR must be $80 \%$ of the farm area; (ii) for farms with Cerrado vegetation (wooded grasslands), the LR is 35\%; (iii) if a farm has open savannas ("campos gerais" in Portuguese) the LR is 20\%. If a farm has an LR deficit, farmers can replant to erase the deficit or purchase environmental quotas (CRA in Portuguese) with farms that have an LR surplus and are located in the same biome. All farmers must replant any LR that was cleared after 22 July 2008 without an official permit.

All information about land use on private farms must be declared in the Rural Environmental Registry (CAR in Portuguese). CAR records are available through an online system called the National Rural Environmental Registry System (SICAR in Portuguese), which, as of 2018, contained more than five million declared farms [29]. The CAR data allow environmental agencies to assess compliance with the FC, ASM, and CA. For example, some studies have combined the CAR data with land cover maps and found that there is low compliance with the FC [30], especially when compared to compliance with the ASM [19] and CA [5,31,32].

The ASM and the CA are the firsts zero-deforestation commitments implemented in the tropics. It began in 2006 with the ASM [19], when international pressure led by Greenpeace influenced a coalition of soy buyers to vow to not buy soy from cleared areas in the Amazon biome [3]. Since the ASM was signed, the Amazon biome has been virtually free of new clearing due to soy $[19,20]$. Similarly, in 2009 the Amazon's largest meatpackers began signing CA with federal prosecutors (the "Beef TAC") and with Greenpeace (the "G4"). Both the G4 and the Beef TAC have similar objectives: To exclude suppliers who have recently engaged in deforestation from the cattle supply chain [5]. The G4 seeks zero deforestation, while the Beef TAC aims for zero illegal deforestation.

In contrast to the ASM, though, the effect of the CA in reducing deforestation has not yet been significant due to inadequate monitoring approaches and to the leakage and laundering of cattle raised on properties with recent deforestation [5,31-33]. While soybean fields are static and there are annual maps available to monitor them [34], cattle move from farm to farm, and there is no precise information available about this movement, making them a challenge to trace [35]. In the absence of cattle traceability information, ranchers with deforestation can either move cattle to regions not yet monitored by the CA (leakage) or send the cattle to farms free of deforestation prior to sale to a slaughterhouse that has signed the CA (laundering). However, recent efforts have tried to connect animal movement data with farm boundaries to better understand the characteristics of Brazil's cattle supply chain and to pinpoint solutions to reduce deforestation for beef production in the country [31,32,36,37].

\section{Materials and Methods}

Our study region includes the Amazon and Cerrado biomes, which occupy, in whole or in part, 17 Brazilian states (nine in the Amazon and 12 in the Cerrado) (Figure 1). These biomes also contain 57\% 
of Brazil's agriculture-driven clearing [38], more than 160,000 species of plants, fungi, and animals [22], and serve as essential reservoirs for much of Brazil's water and carbon stocks [25].

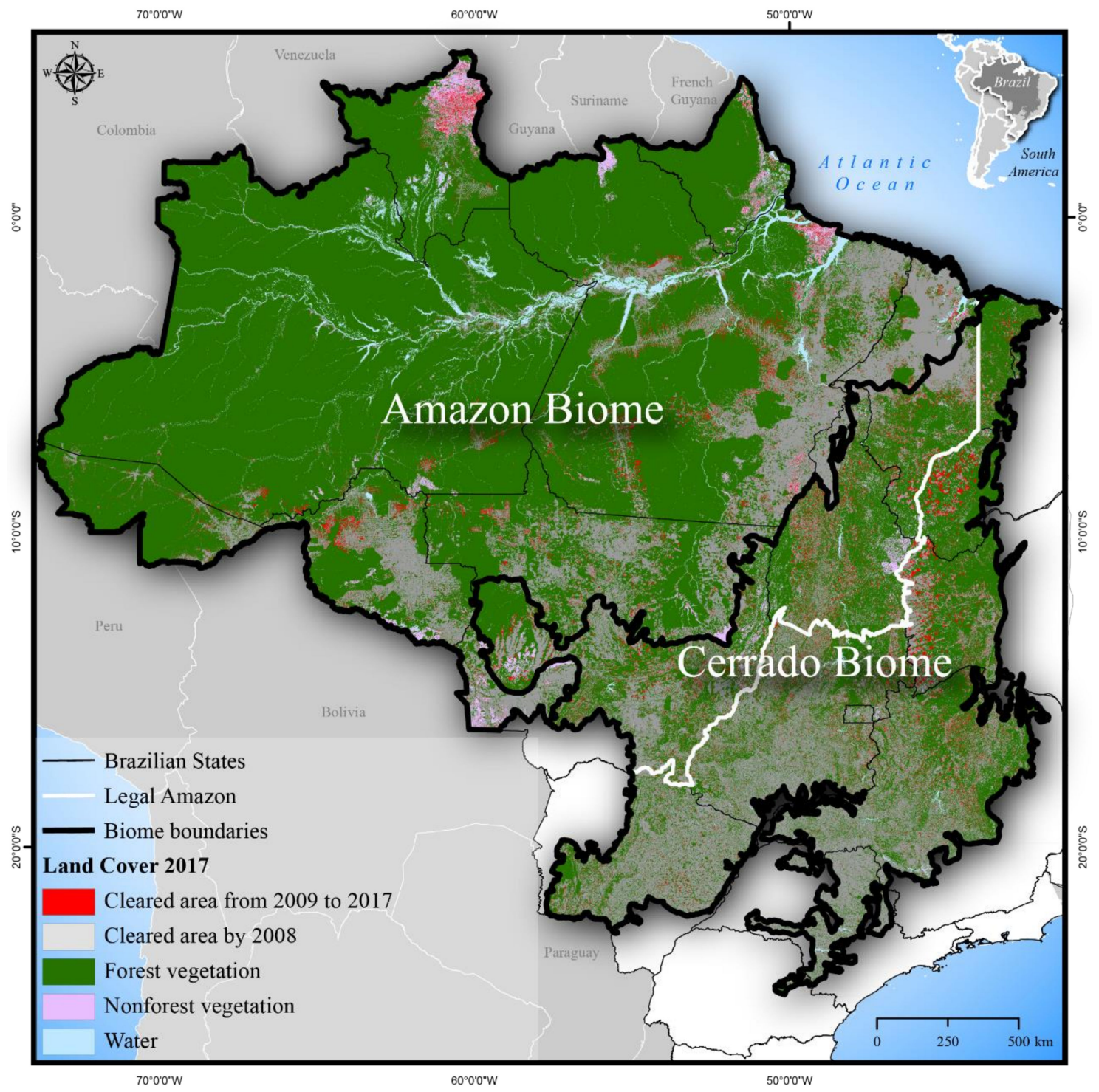

Figure 1. Synthetic land cover map depicting areas of forest, nonforest, and clearing through 2017 within the Amazon and Cerrado biomes and the Legal Amazon. This map was produced based on PRODES, TERRACLASS, and MAPBIOMAS (collection 2.3) data. More details in Section 3.1.

\subsection{Datasets and Data Preparation}

Using ArcGIS 10.3, we organized a set of spatial data to generate our four scenarios (Table A1 and Figure A1 in Appendix A). These data portray the land coverage and land use in 2017 in both biomes and are compatible with a scale of 1:100,000 with a pixel size of 60 by $60 \mathrm{~m}$. Before computing these scenarios, the data were prepared using these four steps:

- $\quad$ Step 1. Creation of a synthetic land cover map for 2017.

We built a synthetic land cover map for the Amazon and Cerrado as of 2017 and used it to identify the areas cleared through that year, as well as the remaining forest and nonforest vegetation. Our first step was to create a map of clearings showing (i) the regions cleared by 2008 and (ii) from 2009 to 2017. For the map of cleared areas in the Amazon, we utilized only the data from PRODES Amazon and MAPBIOMAS within the Amazon biome boundary [39]. We used MAPBIOMAS data 
only within areas of nonforest vegetation mapped by PRODES. The clearings map for Cerrado was based on the data from PRODES Cerrado. Next, we identified the remaining forest and nonforest vegetation. For the Amazon, we used PRODES, TERRACLASS, and MAPBIOMAS and began by selecting only the "forest" lands class from PRODES, and the "secondary forest" from TERRACLASS up to 2014. From MAPBIOMAS, we selected only the forest and nonforest classes located within the "nonforest" class mapped by PRODES. Similarly, we identified remaining Cerrado vegetation from the TERRACLASS "natural vegetation" class and the MAPBIOMAS nonforest classes. Finally, we overlaid the map of cleared areas upon that of remaining vegetation to produce a synthetic land cover map for 2017. Secondary forest areas that were located within cleared areas were maintained as "forest". Areas of remaining nonforest vegetation that overlapped with cleared areas were classified as cleared.

- Step 2. Creation of a mask for the ineligible areas for cropland and pasture.

Land located within protected areas, military areas, urban areas, along roads, mining areas, or water bodies was considered ineligible for cropland and grazing [12]. These areas were removed from the synthetic land cover map.

- Step 3. Identification of the areas suitable for cropland expansion.

We identified suitable and unsuitable areas for cropland expansion using a map of soy suitability. Soy is the dominant crop in the Amazon and Cerrado biomes; it is planted on $90 \%$ of the cropland in the two biomes and can serve as a reasonable proxy for estimating areas most suitable for all types of crops in the region.

We assessed suitability using two soy suitability maps generated by Agrosatélite [40] and by Soares-Filho et al. [12]. Both maps cover the Amazon and Cerrado biomes and were merged into a single dataset for our analyses. The Agrosatélite map is based on the EMBRAPA methodology; it identified biophysical restrictions for the occurrence of soy within $30 \times 30-\mathrm{m}$ grid cells [40]. We maintained areas of this map where no restrictions on soy production had been reported. The second map, from Soares-Filho et al. [12], is also based on environmental conditions and has a $60 \times 60 \mathrm{~m}$ spatial resolution. For this map, we retained grid cells, with a value for soy higher than 60 (range 0 to 100), which indicates suitability. The two soy suitability maps were then superimposed, and grid cells were classified as "suitable for cropland" if either of the input maps reported suitability. Next, we excluded areas mapped as cropland as of 2017 by TERRACLASS and Agrosatélite. The remaining areas were classified as "unsuitable for cropland".

All land unsuitable for cropland was considered suitable for pasture. We assumed that when land is suitable for crops, the farmer will choose to plant rather than use the land for pasture because crops are more profitable than ranching [41]. We also excluded areas considered ineligible for cropland and pasture from our analyses (identified in Step 2). Next, we overlaid our suitability map with the synthetic land cover map for 2017 (from Step 1) to estimate the most suitable areas that could be cleared for cropland or pasture use.

- $\quad$ Step 4. Estimation of Forest Code compliance

We used two datasets to estimate FC surpluses and deficits (Figure A1): (i) 12th order watersheds (a proxy for farms) and (ii) CAR-delineated farms. The rationale for using watersheds as a proxy for farms was to provide a contiguous border-to-border estimate since CAR data only cover an area equivalent to $66 \%$ and $46 \%$ of the Cerrado and Amazon region that is eligible for cropland and grazing, respectively. This proxy-based approach is comparable to that of Stickler et al. [10] and Soares-Filho et al. [12]. For the CAR farm dataset, we downloaded farm boundaries declared at the SICAR website in December of 2017 [29]. Due to the high level of self-intersection among the CAR farms, we excluded farms whose area overlapped more than $5 \%$ of any neighboring farms 
using the tabulate intersection tool in ArcGIS [42]. For both datasets, we considered only farms within the mask of eligible areas. Results from the watershed scale analysis are reported in the main text of this paper and results for the CAR farm dataset can be found in the Appendix B.

\subsection{Generating the Policy Scenarios}

Below, we describe the central assumptions of each scenario and how they were estimated in our spatial analysis (Table 1).

Table 1. Summary description of the assumptions considered within the policy scenarios we modeled.

\begin{tabular}{|c|c|c|}
\hline Scenario & Assumption & What Was Modeled \\
\hline Zero-clearing (ZC) & $\begin{array}{l}\text { - No new clearing of any } \\
\text { type of vegetation }\end{array}$ & $\begin{array}{l}\text { - Cropland } \\
\text { - Current clearing suitable or unsuitable } \\
\text { for cropland }\end{array}$ \\
\hline $\begin{array}{l}\text { Legal clearing of nonforest } \\
\text { vegetation (LC-NF) }\end{array}$ & $\begin{array}{l}\text { - Legal clearing of } \\
\text { nonforest vegetation }\end{array}$ & $\begin{array}{l}\text { - Areas from the ZC scenario } \\
\text { - Legal clearing of nonforest vegetation } \\
\text { suitable or unsuitable for cropland }\end{array}$ \\
\hline $\begin{array}{l}\text { Legal clearing of all types of } \\
\text { vegetation (forest and nonforest) } \\
\text { (LC-AllVeg) }\end{array}$ & $\begin{array}{l}\text { - Legal clearing of all types } \\
\text { of vegetation }\end{array}$ & $\begin{array}{l}\text { - } \quad \text { Areas from the ZC scenario } \\
\text { Legal clearing of all types of vegetation } \\
\text { suitable or unsuitable for cropland }\end{array}$ \\
\hline Full legal compliance (FLC) & $\begin{array}{l}\text { - Legal clearing of all types } \\
\text { of vegetation } \\
\text { Potential for } \\
\text { environmental quotas } \\
\text { (CRA) or replanting }\end{array}$ & $\begin{array}{l}\text { - } \quad \text { Areas from the ZC scenario } \\
\text { - Legal clearing of all types of vegetation } \\
\text { suitable or unsuitable for cropland } \\
\text { Potential for CRA or replanting suitable } \\
\text { or unsuitable for cropland }\end{array}$ \\
\hline
\end{tabular}

\section{- $\quad$ Zero-clearing $(\mathrm{ZC})$}

In this baseline scenario, we show the amount of cleared land that is suitable for cropland and pasture expansion without further clearing of any type of vegetation, whether forest or nonforest. Thus, this scenario divides the total cleared area of the study region into three classes. The first class represents the area used for cropland by 2017. The second class comprises non-cropland areas that have been previously cleared and are suitable for cropland. The third class consists of non-cropland areas that have been previously cleared that are unsuitable for cropland but may be suitable for pasture. For the second and third classes, we also calculated how much of these areas were devoted to pasture as of 2017.

\section{- Legal clearing of nonforest vegetation (LC-NF)}

The intent of this scenario was to calculate the surplus of nonforest vegetation that could be legally cleared under the FC and was suitable or unsuitable for cropland. This surplus of nonforest vegetation could be cleared without triggering the ASM or CA monitoring systems that are currently active in the Amazon. This scenario ultimately points to a reduction in the amount of total native vegetation that could remain, and to an increase in the whole area that could be used for cropland or for pasture, when the surplus areas are combined with the already cleared areas from the ZC scenario. This scenario, when compared with the LC-AllVeg scenario (described below), also assesses the importance of including all types of Cerrado vegetation, should similar agreements be implemented there.

To calculate the surplus of nonforest vegetation that could be legally cleared, we first superimposed the farm or watershed boundaries layers (Figure A1K-L) on our synthetic land cover map for 2017 and calculated the amount of forest and nonforest vegetation within each farm. We then estimated 
the LR for each farm and the LR surplus and then limited this surplus to the area of nonforest vegetation within the farm. We considered only the vegetation located outside the APPs (Figure A1G) to be LR surplus that could be cleared. For example, in a farm with a 100-hectare LR surplus located outside APPs, with 150 hectares (ha) of nonforest vegetation and 50 ha of forest vegetation, all surpluses would be distributed to nonforest vegetation (100 ha). When there was not enough nonforest vegetation to cover the entire LR surplus, only the nonforest vegetation was allocated for clearing, even if it was less than the total LR surplus. We also assumed that nonforest vegetation in areas suitable for cropland would be cleared before areas that were unsuitable for cropland. The suitability classification of previously cleared areas was the same as in the ZC scenario.

- $\quad$ Legal clearing of all types of vegetation (forest and nonforest) (LC-AllVeg)

Under this scenario, we calculated the surplus of LR of any vegetation that could be legally cleared under the FC. This approach to estimating the LR surplus is similar to that used in the LC-NF scenario above but does not limit the type of vegetation only to nonforest. Again, we estimated how much of this surplus was suitable for cropland. The previously cleared area remained the same as in the ZC scenario.

- $\quad$ Full legal compliance (FLC)

For the final scenario, we estimated the LR deficits that would need to be replanted or compensated using CRA for farms to be fully compliant with the FC, which, in essence, are removed from the total amount of cleared area and LR surplus estimated in the LC-AllVeg scenario. For these estimates, we began by calculating the LR requirements for replanting on each farm. We first estimated the remaining vegetation in 2008 by adding the clearing that occurred from 2009 to 2017 to the vegetation remaining in 2017. We then calculated the LR surplus as of 2008 using the same approach as in the LC-AllVeg scenario. The extent of clearing that occurred after 2009 and exceeded the LR surplus in 2008 was assigned to replanting. For CRA, we combined the farm size (Figure A1J) and the percentage of LR that should be replanted based on the proportion of the municipality where the farm is located that is covered by protected areas (Figure A1I). Finally, we estimated how much of the CRA was suitable or unsuitable for cropland.

\subsection{Potential Carbon Emissions and Biodiversity Impacts of Each Scenario}

\section{- Carbon emissions}

We calculated carbon dioxide $\left(\mathrm{CO}_{2}\right)$ emissions using average emission factors for both forest and nonforest vegetation that were either suitable or unsuitable for cropland (Table A2). These emission factors represent the carbon stock in above- and below-ground biomass, as well as the vulnerable fraction of soil organic carbon (SOC) to a depth of $30 \mathrm{~cm}$. To calculate these factors, we overlaid the synthetic land cover map with carbon maps specific to each carbon pool, as described below. We did not calculate $\mathrm{CO}_{2}$ emissions for the $\mathrm{ZC}$ scenario because we assumed that there was no forest or nonforest vegetation cleared in this scenario.

Mean above-ground biomass carbon stocks (AGBC) were calculated from an AGBC map [43]. Below-ground biomass carbon stocks (BGBC) were derived from a matching map of below-ground BGBC that we created using a regression model [44] that predicts BGBC based on covariance with mean annual temperature (MAT), tree phylogeny (angiosperms or gymnosperms), and the history of forest management, as used and described in Spawn et al. [45]. Spatial estimates of MAT (1970-2000) were taken from the WorldClimV2 data set [46], and management history was inferred from our synthetic land cover map. In the absence of compatible spatial information on locally dominant forest phylogenies, we assumed that all forests in our study region were dominated by angiosperms.

Committed emissions from SOC stocks to a depth of $30 \mathrm{~cm}$ were mapped by spatially applying expected SOC stock change estimates to SOC maps from the SoilGrids250v2 dataset [47] following 
the general approach of Spawn et al. [45]. Mean stock change estimates represent the fraction of the initial SOC stock that is lost upon conversion to cropland and were taken from Don et al. [48]. Three distinct estimates representing conversion of (i) primary forest, (ii) secondary forest, and (iii) grasslands to cropland were used and spatially stratified according to the pre-conversion landcover type reported by our synthetic landcover map.

Emissions factors in initial units of carbon we converted to $\mathrm{CO}_{2}$ equivalents using the molar mass ratio ( $44 \mathrm{~g} \mathrm{CO}_{2}: 12 \mathrm{~g} \mathrm{C}$ ). We then multiplied these average factors by the areas that can be legally cleared as estimated in each of the scenarios. In the case of the FLC scenario, we assumed that the areas of legal clearing potentially protected by CRA would avoid some of the emissions associated with the LC-AllVeg scenario.

\section{- $\quad$ Biodiversity}

We analyzed the impact of each policy on biodiversity as the change in the probability that a species will persist due to proportional loss of its extent of suitable habitat (ESH), an approach that allows us to integrate spatially-explicit information on specific anthropogenic land use and the ecology of individual species. ESH describes the intersection of a species' historical geographic range with its environmental preferences [49], measured based on vegetation cover and elevation [50].

For each scenario, we assessed potential global extinctions of endemic and near-endemic species of amphibians, birds, and mammals within the Amazon, Cerrado, and the region encompassed by both biomes (hereafter both biomes). The ZC scenario served as the baseline to calculate the biodiversity score. A species was defined as being present in a grid-cell if all of the following conditions were met: (i) the cell was within the range of the species [51], (ii) its local elevation was within the species' elevational range limits, and (iii) its land cover was included on the species list of suitable habitats (Table A3). For migratory species, ESH was mapped considering seasonal differences in their habitat preferences.

Species with $\geq 70 \%$ of their global range inside the Amazon and Cerrado study regions combined were considered endemic. For migratory species, this criterion was applied to their seasonal ranges (resident, breeding, non-breeding, and migratory separately), as the persistence of the species depends on each cyclical scale independently [52]. For each region, this resulted in the following numbers of ESH models for each vertebrate group: (i) Amazon ( $\mathrm{N}=284$ ): amphibians (81), birds (124), and mammals (79); (ii) Cerrado ( $\mathrm{N}=109$ ): amphibians (60), birds (27), and mammals (22); and (iii) both-biomes ( $\mathrm{N}=458)$ : amphibians (156), birds (191), and mammals (111).

Next, we estimated the effects of the scenarios on the probability of persistence of each species. Following the procedure and analysis from Thomas et al. [53] we calculated the change in persistence of the ESH. For each scenario, we calculated the marginal value of the loss of remaining suitable habitat as:

$$
\Delta P_{i, k}=\left(E_{2017, k}\right)^{z}-\left(E_{\text {scenario } i, k}\right)^{z}
$$

where $\Delta P$ is the remaining suitable habitat, $i$ is each scenario, $k$ is the species, $E_{2017}$ is the remaining proportion of ESH in 2017 (including eligible and ineligible land for cropland and pasture, as defined in Section 3.1), $E_{\text {scenario }}$ is the remaining proportion of ESH after removing the eligible vegetation vulnerable to a legal clearing (vulnerable vegetation) from $E_{2017}$ according to each scenario, and $z$ is a coefficient relating to the probability of persistence to population size.

We assessed the remaining proportion of ESH in $2017\left(E_{2017}\right)$ against the original ESH of the species. To do this, we used a vegetation map of Brazil, representing pre-industrial times [54]. For migratory species, we calculated an overall marginal value from the $\Delta P_{i, k}$ that was derived separately for the ESH of breeding and non-breeding species and the two values were then combined multiplicatively, as previously suggested by empirical [55] and theoretical studies [56]:

$$
\Delta P_{i, k, \text { mig }}=P_{b, 2017} \times P_{n b, 2017}-P_{b, \text { scenario } i} \times P_{n b, \text { scenario } i}
$$

where $P_{b}$ and $P_{n b}$ are the persistence scores within the breeding and non-breeding ranges, respectively. 
For each species, we calculated the $E_{\text {scenario }}$ as the sum of vulnerable vegetation ESH across all 12th order watersheds contained within corresponding biomes. The following rules were applied to calculate vulnerable vegetation ESH at watershed or farm level: (i) if ESH is 0 or vulnerable vegetation is 0, then vulnerable vegetation $\mathrm{ESH}$ is 0; (ii) if ESH is larger than the vulnerable vegetation, then the vulnerable vegetation ESH was calculated as the ratio of vulnerable vegetation to ESH; and (iii) if ESH less than equal the vulnerable vegetation, then the entire area of ESH was considered vulnerable.

\section{Results}

\subsection{Land Available for Cropland and Pasture}

Under the ZC scenario, we found 152 million hectares (MHa) of cleared area as of 2017 across the Amazon and Cerrado biomes (Figure 2). One-fifth of the total cleared area (31 MHa) was used as cropland, and most of this cropland was in the Cerrado biome (26 MHa) (Figure 3C). Of the remaining cleared area, $74 \mathrm{MHa}$ was suitable for cropland (40 MHa in the Cerrado and $34 \mathrm{MHa}$ in the Amazon). Cropland could expand by $238 \%$ across both biomes combined (from $31 \mathrm{MHa}$ to $105 \mathrm{MHa}$ ), mainly at the expense of pasturelands. A large portion (64 MHa) of the cleared area suitable for cropland was already pasture in 2017.

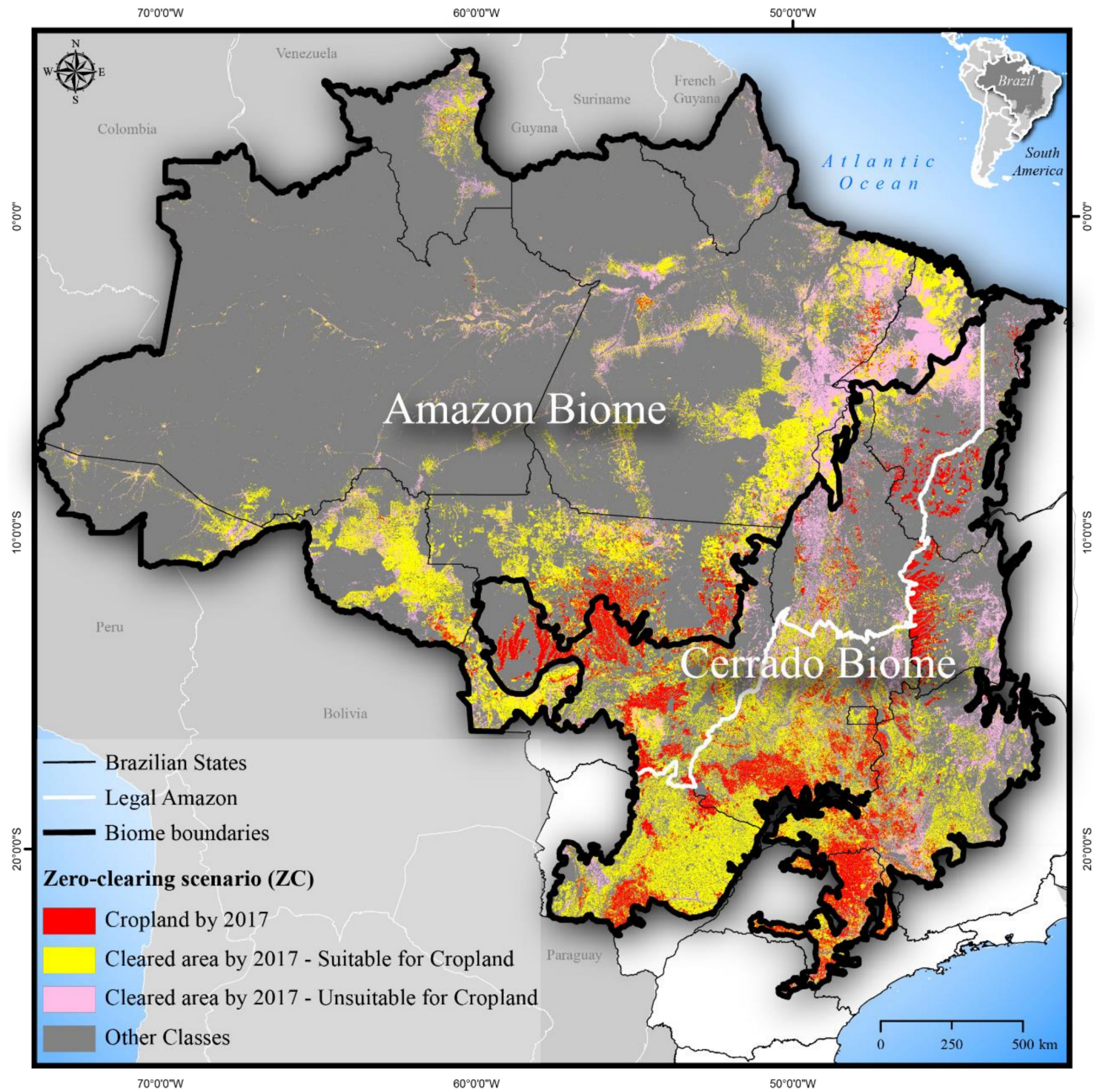

Figure 2. Areas cleared by 2017, calculated under the zero-clearing scenario (ZC). 


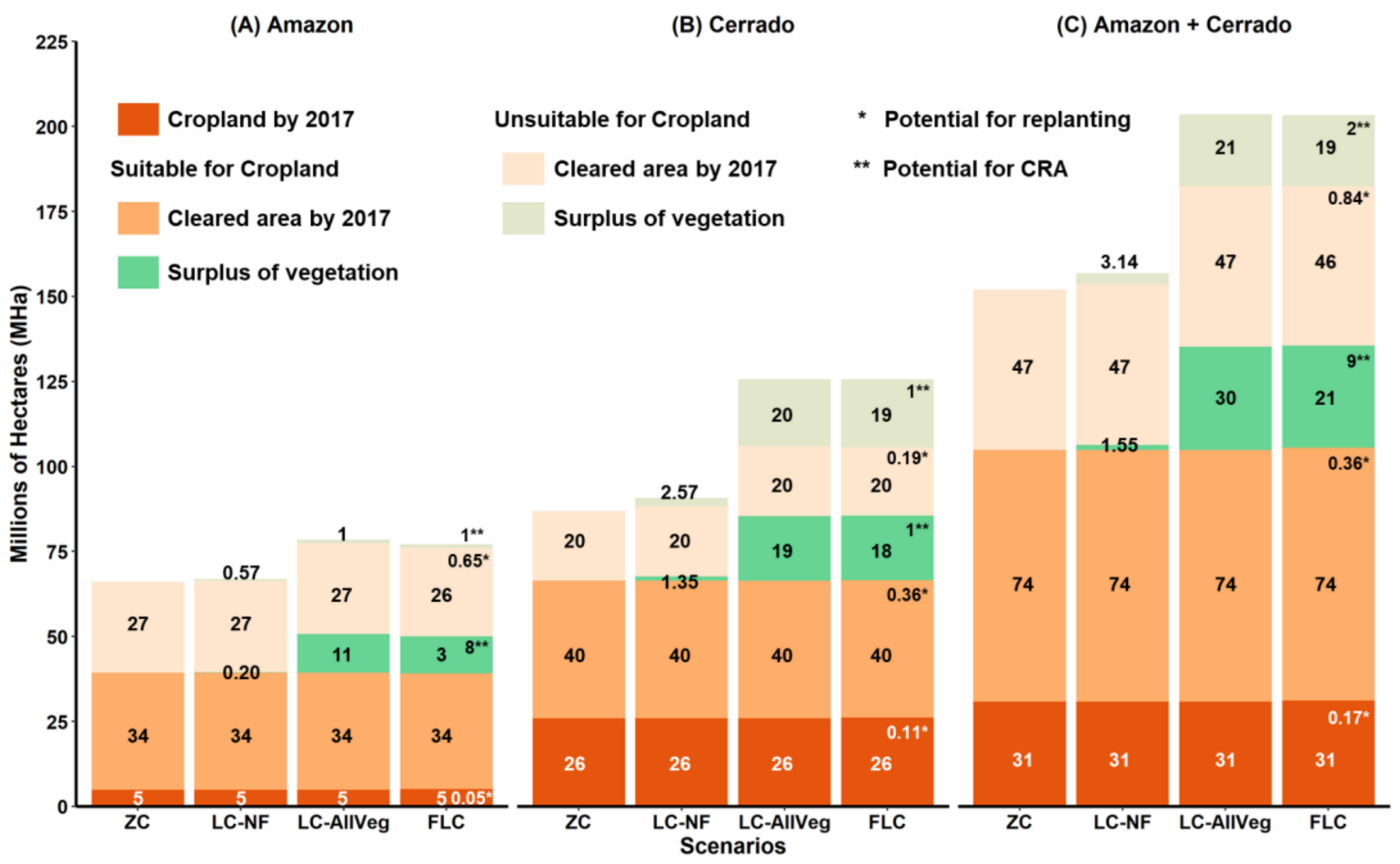

Figure 3. Land areas for the Amazon (A), Cerrado (B), and both biomes combined (C) under four policy scenarios: zero-clearing (ZC), legal clearing of nonforest vegetation (LC-NF), legal clearing of all types of vegetation (forest and nonforest) (LC-AllVeg), and full legal compliance (FLC). The legal clearing presented in this figure was calculated from the border-to-border extent of 12th order watersheds within the areas eligible for crops and pasture.

Opportunities for agricultural expansion without additional clearing were most prevalent in the Cerrado, though there remained a sizeable amount of suitable area in the Amazon as well. In the Cerrado, the current extent of cropland (26 MHa) could expand to as much as $66 \mathrm{MHa}$, an increase of $40 \mathrm{MHa}$ or $154 \%$. Most of these cleared and suitable areas are in the southern part of the Cerrado biome and in proximity to the "arc of deforestation" along the southern edge of the Amazon biome. In the Amazon, cropland can potentially expand by as much as $680 \%$ (from $5 \mathrm{MHa}$ to $39 \mathrm{MHa}$ ) on existing cleared areas that are suitable for cropland.

Two-thirds of this cleared area was concentrated in the Amazon biome (27 MHa), primarily in the northern part of the state of Pará (Figure 2). One-third of the total cleared area in the two biomes (47 MHa) was unsuitable for cropland, and, as expected, $36 \mathrm{MHa}$ of this area was already managed as pasture (Figure 3). In the Cerrado biome, up to $20 \mathrm{MHa}$ of these cleared areas were unsuitable for cropland, and most of them were distributed in the north and central portions of the biome.

In the LC-NF scenario, under which the smallest amount of vegetation could be cleared beside the ZC scenario, only 5 MHa could be cleared across both biomes, with the majority of this area $(84 \% ; 4.2 \mathrm{MHa})$ located in the Cerrado. About half of this vegetated land is suitable for crops. In all, the Amazon has $1 \mathrm{MHa}$ of surplus nonforest vegetation under the FC, and neither the ASM nor the CA currently monitors this area, increasing the likelihood that it will be cleared.

The LC-AllVeg scenario allowed for the most additional clearing across both biomes. We found that $51 \mathrm{MHa}$ could be cleared legally under the FC, on top of the areas that were already cleared as of 2017. Nearly $30 \mathrm{MHa}$ of this land with surplus natural vegetation would be suitable for cropland. Due to its lower LR requirements, the Cerrado biome comprises most of the vegetation (76\%) that can be legally cleared, and just over half of these surplus areas in the Cerrado are suitable for cropland expansion. In the Amazon biome, $11 \mathrm{MHa}$ of the legally clearable land would be suitable for crops, and only $1 \mathrm{MHa}$ 
would not. If all farms in the two biomes were to deforest the maximum area of land allowed under the FC, the total potential cleared area could increase from $152 \mathrm{MHa}$ to $203 \mathrm{MHa}$ or $34 \%$ over the ZC scenario.

Under the FLC scenario, we found that just over $1 \mathrm{MHa}$ of cleared areas would need to be replanted, and $11 \mathrm{MHa}$ could be compensated under environmental quota schemes in both biomes. Thus, for all farms to achieve FC compliance, there are only $40 \mathrm{MHa}$ (51 MHa-11 MHa) of LR surplus that can be legally cleared. Of these $40 \mathrm{MHa}, 21 \mathrm{MHa}$ are suitable for crops and $19 \mathrm{MHa}$ are unsuitable for crops. Thus, the total cleared area under this scenario could be as much as $192 \mathrm{MHa}$, an increase of $26 \%$ compared to the ZC scenario. Results from CAR farm boundary analyses for all scenarios were similar to those reported here at watershed boundaries but were slightly lower because the CAR farms cover a smaller area than the watersheds (details on Appendix B).

\subsection{Impact of the Four Policy Scenarios on Carbon Emissions}

The impacts of even legal clearing on carbon emissions, from the conversion of natural vegetation and subsequent effects on the underlying soil, will increase Brazil's future emissions (Figure 4). Our results show that clearing of all remaining native vegetation that can be legally cleared could result in as much as 9 petagrams of carbon dioxide equivalents $\left(\mathrm{PgCO}_{2} \mathrm{e}\right)$ of emissions, with $25 \%$ $\left(2 \mathrm{PgCO}_{2} \mathrm{e}\right)$ coming from the Amazon and the remainder $\left(7 \mathrm{PgCO}_{2} \mathrm{e}\right)$ from the Cerrado. These emissions would be equivalent to 21\% of Brazil's cumulative emissions between 1986 and 2017 for the land-use change sector $\left(46 \mathrm{PgCO}_{2} \mathrm{e}\right)$ [57]. Limiting clearing of just nonforest vegetation (LC-NF) would reduce emissions by $1 \mathrm{PgCO}_{2} \mathrm{e}$, where $52 \%\left(0.52 \mathrm{PgCO}_{2} \mathrm{e}\right)$ could come from the Cerrado where most nonforest vegetation is concentrated, and by $0.48 \mathrm{PgCO}_{2} \mathrm{e}$ from the Amazon biome. Regarding the Amazon biome, the emissions from the nonforest vegetation were equivalent to $85 \%$ of the emission from Cerrado due to higher average emission factors (details on Table A2).

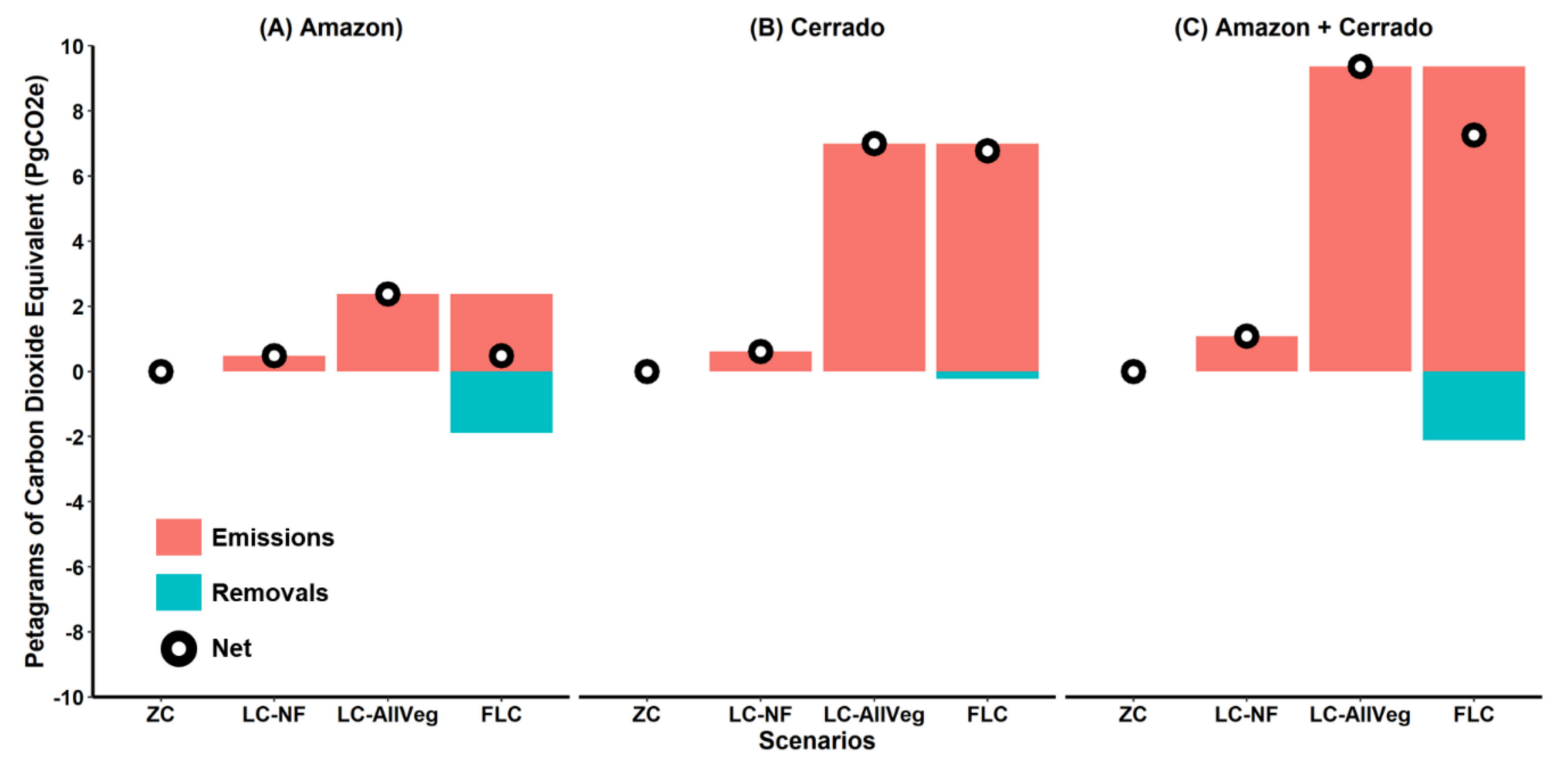

Figure 4. Estimated emissions, removals, and net CO2e emissions for the Amazon (A), Cerrado (B), and both biomes combined (C) under four policy scenarios: zero-clearing (ZC), legal clearing of nonforest vegetation (LC-NF), legal clearing of all types of vegetation (forest and nonforest) (LC-AllVeg), and full legal compliance (FLC).

However, if CRA schemes were implemented according to the FC (FLC scenario), leading to greater protection for surplus vegetation, potential emissions would fall to $7 \mathrm{PgCO}_{2} \mathrm{e}(77 \%$ of the emissions from the LC-AllVeg scenario). In the Amazon, the reduction in emissions could be as much as $80 \%$ under the FLC scenario compared to the LC-AllVeg scenario. Yet, in the Cerrado, this reduction would be only $3 \%$ due to the fact that there is so little illegal clearing in the Cerrado associated with the lower restrictions on clearing of the LR. Thus, even if the FC were fully implemented in the Cerrado, 
legal clearing alone could result in the emission of $6.79 \mathrm{PgCO}_{2} \mathrm{e}$, almost $400 \%$ of the emissions from the Amazon biome without implementing the FC in full.

\subsection{Impact of the Four Policy Scenarios on Biodiversity Loss}

Clearing of all LR surplus under the LC-AllVeg scenario would lead to a marked decline in biodiversity (Figure 5). Under the LC-AllVeg scenario, the biodiversity persistence score dropped from 0.94 to $0.92,0.82$ to 0.72 , and 0.89 to 0.85 in the Amazon, Cerrado, and across both biomes combined, respectively. Likewise, in the LC-NF scenario, clearing of land unsuitable for crops had a higher mean impact on biodiversity than the clearing of similar land within the Amazon by a factor of ten $(-0.013$ unsuitable vs. -0.0013 suitable), while in the Cerrado the clearing of both types of land had a similar effect on biodiversity persistence ( -0.05 unsuitable vs. -0.05 suitable).

Of interest, the observed decline in biodiversity persistence under scenarios LC-NF and LC-AllVeg was reduced under scenario FLC. This happened because under the FLC scenario $4 \%$ and $20 \%$ of the most vulnerable ESH areas could fall in areas likely to be allocated to CRA in the Amazon and Cerrado, respectively. The recovery of the biodiversity persistence score was more pronounced in the Amazon.

We note that even under the ZC scenario, the accumulated clearing had already affected species' probability of persistence in both biomes (Figure 5, scenario ZC). Scores for the other scenarios show how additional clearing would thus further reduce biodiversity persistence. Without new clearing, the remaining ESH for endemic species was $89 \%$ of the pre-industrial times, on average for the Amazon and Cerrado biomes combined. Overall, of the total remaining ESH, 38\% across both biomes was suitable for agricultural expansion. Furthermore, $4 \%$ of the suitable ESH in the Amazon and up to $25 \%$ suitable ESH in the Cerrado was vulnerable to the legal clearing.

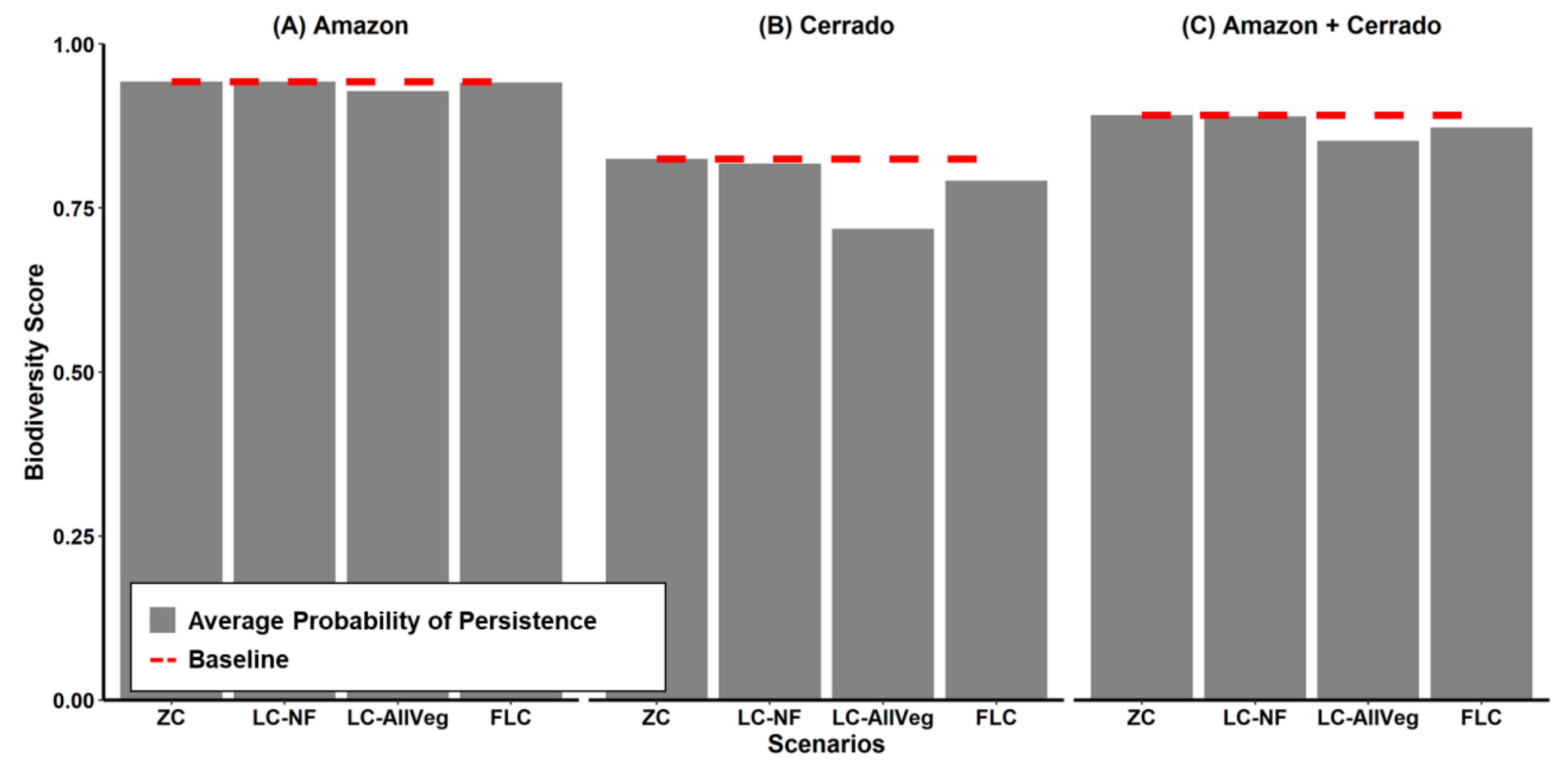

Figure 5. Changes in biodiversity persistence score for endemic vertebrate species under four clearing scenarios for (A) Amazon, (B) Cerrado, and (C) both biomes combined (based on z = 0.25; see Table A3). The biodiversity scores show persistence due to the proportional loss of suitable habitat. The red dashed line is the average probability of persistence without new clearing (ZC Scenario).

\section{Discussion}

\subsection{Challenges to Containing Legal Clearing in the Amazon and Cerrado Regions}

As with other studies, we found a considerable amount of land area that could be legally cleared in the Amazon and the Cerrado regions $[12,58,59]$. However, our study goes beyond previous studies 
to quantify the proportion of legally clearable land that is suitable for crops, which sheds light upon the relative risks of cropland expansion in the region. For example, according to the LC-AllVeg scenario, $51 \mathrm{MHa}$ may be legally cleared, with $30 \mathrm{MHa}$ being suitable for cropland. The remaining $21 \mathrm{MHa}$ could be used for pasture; $24 \%$ (12 MHa) of the potential area vulnerable to legal clearing is concentrated in the Amazon; the largest share (11 MHa) is suitable for crops, though this area should be afforded at least some protection by the ASM since soy is the most valuable crop produced there. The CA, even with its limitations [5,31-33], could help to protect the additional $1 \mathrm{MHa}$ that is more suitable for pasture, in addition to the areas suitable for crops. In the case of the Cerrado, 39 MHa may be legally cleared, including areas that are suitable for crops and those which are not, which emphasizes the need to expand both the ASM and CA protections for this biome.

Although substantial amounts of vegetation can be legally cleared, the FC includes additional provisions that could help reduce these totals [60]. We estimate that as much as $22 \%$ (11 MHa) of legal clearing could be avoided under full implementation of the FC where landowners offset vegetation deficits through participation in CRA. However, most of these reductions would take place in the Amazon, where CRA could prevent around 75\% (9 MHa) of the legal clearing. The effect on the Cerrado would be small, with $2 \mathrm{MHa}$ of area suitable for CRA ( $\%$ of the surplus LR). CRA policy is still being developed but may become a complementary income source for landowners with an LR surplus. Instead of legally deforesting the LR surplus, the landowner would potentially protect the standing vegetation by selling CRA quotas to ranchers that have LR deficits in the same biome (mostly in the Amazon).

However, to halt legal clearing in the Amazon and Cerrado regions, there are still some key challenges. First, current monitoring systems in the Amazon do not cover nonforest vegetation, which limits our ability to measure the clearing of these areas [61,62]. Our results also highlight the significant area of nonforest vegetation left out of the CA and ASM, which both rely on clearing data from INPE's PRODES to determine compliance. For example, $0.77 \mathrm{MHa}$ of nonforest vegetation is vulnerable to the legal clearing in the Amazon biome (LC-NF scenario) which, consequently, could be legally cleared without violating these agreements. The recently launched PRODES Cerrado, however, does not differentiate between forest and nonforest vegetation, which means that any future agreements in this biome could potentially avoid this concern if they rely on official clearing data like the agreements in the Amazon. Our results show that just under 4 MHa of the total of 39 MHa of vulnerable vegetation in the Cerrado are areas of nonforest vegetation.

Second, the fact that the ASM and CA, which some studies indicate have had a positive effect in the Amazon [19,20,33,37,63-66], are not applied within the Cerrado biome further confounds efforts to regulate clearing. To that end, numerous scientists and key stakeholders have called for new agreements for the Cerrado to stave off clearing in the region, much of which may be permissible under the FC $[14,67]$. By allowing up to four times the deforestation within a given farm in the Cerrado compared to in the Amazon, the FC alone is unlikely to control deforestation in this region. Some studies already indicate that zero-deforestation soy production in the Cerrado would be feasible [67,68], which could prevent the direct conversion of 19 MHa. Likewise, a zero-deforestation approach to cattle production in the Cerrado could potentially prevent at least another 20 MHa from being deforested for pasture.

Third, regardless of the policy approach followed, it will likely remain the case that large extents of Brazil's forestlands are privately owned. Deforestation in the Amazon and Cerrado biomes is mostly driven by commodity production of grains and beef [69-71], which is influenced by price variations and demand for these commodities, as well as conservation policies [15]. While some authors suggest that private property may be an effective strategy for combating deforestation because insecure property leads to higher deforestation rates [72]. Others argue that Brazil still needs to improve its land governance to reduce deforestation, given to insecure property rights, especially on public lands that often suffer from land speculation and deforestation to attend market demands [73].

Finally, recent pressure to weaken environmental legislation has been a common practice over the last decade and has undermined the efficacy of existing regulations [74-79]. The Brazilian Congress 
is majority led by congressmen who are large landowners, known as the "ruralist" bloc [76,79], and they have worked to weaken environmental legislation through bills and amendments in exchange for political support [80]. One recent effort happened in early 2019, which attempted to revoke the concept of legal reserve determined by the FC $[78,81]$. The primary justification for this bill was the fact that the legal reserve collides with property rights, thus affecting agricultural production in Brazil, especially in the Legal Amazon. However, this bill was not approved and was definitively withdrawn from the Brazilian Federal Senate Plenary. If it had been approved, as much as $135 \mathrm{MHa}$ of vegetation could have potentially been cleared in the Amazon and Cerrado biomes [82].

\subsection{Cropland Could Expand without Clearing, but Cattle Production Must Intensify}

There are large areas in both the Amazon and the Cerrado that are suitable for expanding cropland without additional clearing. The Brazilian Ministry of Agriculture (MAPA in Portuguese) projects that 9 to $24 \mathrm{MHa}$ of additional land will be necessary by 2028 to meet the domestic and international demands for grains produced in Brazil, a maximum increase of $39 \%$ over the total cultivated area of the country in 2017-2018 [83]. That increase could easily be accommodated inside the current $74 \mathrm{MHa}$ of cleared areas that are suitable for crops in the Amazon and the Cerrado regions, without the need for additional clearing and spare the $31 \mathrm{MHa}$ of surplus vegetation suitable for crops and vulnerable to legal clearing, as shown in the LC-AllVeg scenario. However, needs for cropland beyond 2028 could eventually require the full $74 \mathrm{MHa}$.

In the case of ranching, however, the current cleared area may not be enough for cattle production unless there is substantial intensification. The current cattle herd in the Amazon and Cerrado biomes stands at 111 million head [84]. Based on MAPA projections, the cattle herd in these two biomes could grow by $13 \%$ to 125 million head by 2028 [83]. If we apply historic stocking density averages for the region of 1.64 animal unit per hectare $\left(\mathrm{AU} \mathrm{ha}^{-1}\right)$ [85], a total area of $76 \mathrm{MHa}$ (125 million head/1.64 AU ha ${ }^{-1}$ ) would be necessary to accommodate the future herd. If all cleared area suitable for cropland were converted to cropland, the remaining $47 \mathrm{MHa}$ of cleared area unsuitable for cropland that will be available for pasture would not be enough to secure the area required under the MAPA projections without intensification of cattle production. This is because, with the historical stocking ratio, there would be a shortfall of $29 \mathrm{MHa}(47 \mathrm{MHa}-76 \mathrm{MHa})$ of area needed for pasture. Given the reduced pasture area that would be available, stocking rates would have to increase from an average of $1.64 \mathrm{AU} \mathrm{ha}{ }^{-1}$ to $2.66 \mathrm{AU} \mathrm{ha}^{-1}$ (125 million heads/47 MHa), which is well within the potential stocking rates estimated by Arantes et al. [85] under realistic intensification strategies. Without intensification of pastures, clearing for ranching would be likely to encroach on the native vegetation or spill over into other biomes such as the Atlantic Forest or Pantanal. If cropland did not expand beyond the maximum MAPA projections of $55 \mathrm{MHa}(31 \mathrm{MHa}+24 \mathrm{MHa})$, there would be enough pasture area ( $97 \mathrm{MHa}$ ) to accommodate the cattle population requirements in MAPA's projections without additional intensification.

Increasing the intensification of pastures from 1.64 $\mathrm{AU} \mathrm{ha}^{-1}$ to $2.66 \mathrm{AU} \mathrm{ha}^{-1}$ is possible, but it requires investments in technology and technical assistance. Some authors [86] recommend that three conditions could support the intensification of pastures. First, large-scale transfer of knowledge is needed that could enable small and large landowners to learn about new technologies and adopt agricultural practices more focused on intensification. For example, pasture rehabilitation and rotational grazing have the potential to significantly increase the production of beef far beyond $1.7 \mathrm{AU} \mathrm{ha}{ }^{-1}$ on average. One challenge, however, is that most projects for intensifying pasture systems require costly technical support [87]. Second, financial support for ranching based on sustainability criteria is needed, which would help farmers not only increase production but also improve compliance with environmental policies. Finally, increased transparency in livestock supply chains is essential; slaughterhouses must more rigorously monitor direct and indirect suppliers to eliminate further clearing in their supply chains, which could lead to an intensification of pasture. 


\subsection{The Forest Code Has a Limited Effect on Reducing Carbon Emissions and Protecting Biodiversity}

The FC, ASM, and the CA can complement each other to help avoid new carbon emissions and to protect the biodiversity of the Amazon and Cerrado. To this end, the zero-deforestation premises of the ASM and CA (e.g., blocking of sales from farms with recent clearing) need to be strengthened in the Amazon and expanded to the Cerrado. If the ASM and CA are expanded to the Cerrado, about $7 \mathrm{PgCO} 2 \mathrm{e}$ of emissions could be avoided by zero-deforestation. In the Amazon, the role of the ASM and CA is less pronounced because the FC is already very restrictive. While C biomass densities are lower in the Cerrado compared to the Amazon, these stocks are, however, extensive, and therefore significant. By allowing four times more clearing within a given farm in the Cerrado than in the Amazon, the FC, on its own, does little to protect them. Expanding the scope of the ASM and CA to include the Cerrado biome could thus complement the FC and help conserve these $C$ stocks that are poorly protected by existing public policies.

The impact of legal clearing on biodiversity and carbon under the FC could also be mitigated through land protection using the CRA. In the Amazon and Cerrado biomes, a decline in biodiversity could be reduced altogether; the guidelines for the recovery of degraded areas through replanting provided for in the FC can help capture carbon and biodiversity. We estimate that replanting vegetation that has been deforested above the limits allowed by the FC can potentially recover about $0.40 \mathrm{PgCO} 2 \mathrm{e}$ in both biomes. Furthermore, the full implementation of CRA could be prioritized in areas with high carbon and biodiversity densities $[13,60,88,89]$.

\section{Conclusions}

Our scenarios show that there is a maximum of 51 MHa of vegetation in both the Amazon and Cerrado biomes that could be legally cleared under the FC. The legal clearing would create additional room for crops and cattle but could have a significant detrimental impact on local carbon stocks and biodiversity. Thus, expanded efforts to reduce clearing in soy and cattle supply chains are needed. Our findings affirm that without the need for additional clearing, the cropland area in 2017 (31 MHa) could be doubled, which would leave at least $47 \mathrm{MHa}$ of cleared areas that would be likely targets of expansion of pasture intensification projects. Indeed, without cattle intensification, there would likely be leakage or displacement of cattle ranching to other biomes. Thus, policies that restrict land use in private lands while supporting alternative production modes will be needed to balance production and conservation over the long term in Brazil.

Author Contributions: Conceptualization, A.B.J., L.R. and H.K.G.; Data curation, A.B.J.; Formal analysis, A.B.J.; Funding acquisition, L.R. and H.K.G.; Methodology, A.B.J., L.R., H.K.G., A.P.D., C.C.J., and S.A.S.; Project administration, A.B.J., L.R. and H.K.G.; Supervision, A.B.J., L.R. and H.K.G.; Validation, A.B.J., L.R. and H.K.G.; Visualization, A.B.J.; Writing—original draft, A.B.J.; Writing—review \& editing, A.B.J., L.R., H.K.G., A.P.D., C.C.J., and S.A.S. All authors have read and agree to the published version of the manuscript.

Funding: This research was funded by Gordon and Betty Moore Foundation grant number 1810027; Norwegian Agency for Development Cooperation's Department for Civil Society under the Norwegian Forest and Climate Initiative grant number 706055. APD was funded by the Luc Hoffmann Institute and by the Institute of Ecology and Biodiversity-Chile grant number PIA APOYO CCTE AFB170008.

Acknowledgments: We thank Andrew Balmford, Jane Lino, Carlos Saviani, and Leandro Baumgarten for their suggestions on analysis in the preliminary versions of this study. Our paper was improved from comments made by George Allez.

Conflicts of Interest: The authors declare no conflict of interest. 


\section{Appendix A}

Table A1. Sources of the data used to calculate the scenarios.



Table A2. Average emission factors for forested and nonforest vegetation that were suitable or unsuitable for crops in the Amazon and Cerrado biomes.

\begin{tabular}{|c|c|c|c|}
\hline \multirow[t]{2}{*}{ Region } & \multicolumn{3}{|c|}{$\begin{array}{c}\text { Emission Factors in Mega Grams of Carbon } \\
\text { Dioxide Equivalent per Hectare }\left(\mathrm{MgCO}_{2} \mathrm{eHa}^{-1}\right)\end{array}$} \\
\hline & AGBC & BGBC & SOC30 \\
\hline \multicolumn{4}{|l|}{ Amazon biome } \\
\hline Forest vegetation unsuitable for cropland & 433 & 102 & 75 \\
\hline Forest vegetation suitable for cropland & 466 & 108 & 76 \\
\hline Nonforest vegetation unsuitable for cropland & 127 & 31 & 70 \\
\hline Nonforest vegetation suitable for cropland & 82 & 20 & 60 \\
\hline \multicolumn{4}{|l|}{ Cerrado biome } \\
\hline Forest vegetation unsuitable for cropland & 106 & 26 & 55 \\
\hline Forest vegetation suitable for cropland & 96 & 24 & 58 \\
\hline Nonforest vegetation unsuitable for cropland & 79 & 20 & 59 \\
\hline Nonforest vegetation suitable for cropland & 72 & 19 & 58 \\
\hline
\end{tabular}

AGBC: Above-ground biomass carbon (data from Englund et al. [43]). BGBC: Below-ground biomass carbon from Reich et al. [44]. SOC30: Soil carbon loss from soils to a depth of $30 \mathrm{~cm}$ (based on soc stocks from Hengl et al. [47] and estimated losses from Don et al. [48]).

Table A3. Mean decline in the probability of persistence for different scenarios with different biodiversity $z$ coefficients. (Mean \pm Standard error). Data estimated based on hierarchical habitat classification scheme from the International Union for Conservation of Nature (IUCN) [96] and the land cover classification from the Brazilian Institute of Geography and Statistics (IBGE) [97].

\begin{tabular}{cccc}
\hline & $\mathbf{Z}=\mathbf{0 . 2 5}$ & $\mathbf{Z}=\mathbf{0 . 5 0}$ & $\mathbf{Z = 1}$ \\
\hline Amazon biome & & & \\
LC-NF & $0.96 \pm 0.004$ & $0.92 \pm 0.006$ & $0.86 \pm 0.01$ \\
LC-AllVeg & $0.94 \pm 0.003$ & $0.90 \pm 0.006$ & $0.82 \pm 0.009$ \\
FLC & $0.96 \pm 0.004$ & $0.91 \pm 0.006$ & $0.86 \pm 0.01$ \\
\hline Cerrado biome & & & \\
LC-NF & $0.86 \pm 0.010$ & $0.75 \pm 0.016$ & $0.60 \pm 0.024$ \\
LC-AllVeg & $0.78 \pm 0.014$ & $0.63 \pm 0.018$ & $0.43 \pm 0.023$ \\
FLC & $0.84 \pm 0.011$ & $0.72 \pm 0.017$ & $0.55 \pm 0.024$ \\
\hline Both biomes & & & \\
LC-NF & $0.88 \pm 0.007$ & $0.79 \pm 0.013$ & $0.65 \pm 0.018$ \\
LC-AllVeg & $0.82 \pm 0.01$ & $0.70 \pm 0.015$ & $0.52 \pm 0.019$ \\
FLC & $0.87 \pm 0.008$ & $0.76 \pm 0.013$ & $0.60 \pm 0.019$ \\
\hline
\end{tabular}





Figure A1. A simplified representation of the main datasets used in this study. Source of the data: (A) PRODES [92,93]; (B) TERRACLASS [90,91]; (C) MAPBIOMAS [38]; (D) Eligible areas for Cropland and Pasture [12,94,95]; (E) Suitability for Cropland [12,40]; (F) Cropland and Pasture 2017 [38,40,90,91]; (G) Areas of permanent protection (APP) [12]; (H) Legal reserve to protect (\% of the farm area) [12];

(I) Legal reserve to replant (\% of the farm area) [12]; (J) Fiscal module size (Ha) [12]; (K) Watersheds 12th order [12]; (L) Overlap-free CAR farms [29]. 


\section{Appendix B}

We found some differences between the LR surplus and deficit calculated for the watersheds versus the CAR property boundaries. We found a surplus of $4 \mathrm{MHa}$ that can be cleared under the FC in the Amazon (3.7 MHa suitable for cropland), compared to $12 \mathrm{MHa}$ using the watersheds. One potential source of this difference is the fact that watersheds are a border-to-border proxy for property boundaries. Thus, the watersheds show potential LR surplus and deficits in regions with low CAR coverage, such as the extreme western region of the Amazon Biome and where the CAR did not take effect until December 2017. In the Cerrado, the difference was lower, with 26 MHa of LR surplus calculated with the property boundaries compared to $39 \mathrm{MHa}$ estimated with the watersheds. The differences in the Cerrado region were most notable in the southern portion of the biome. In this region, the watersheds had a smaller average size than the rural farms, which may have increased the LR surplus. Regarding the LR deficit, the difference was $2 \mathrm{MHa}$ in the Amazon biome (9 MHa calculated with the watersheds compared to $11 \mathrm{MHa}$ for the properties). In the Cerrado, the difference in the LR deficit was almost $2 \mathrm{MHa}$, with nearly $5 \mathrm{MHa}$ calculated with the properties and $3 \mathrm{MHa}$ with the watersheds.

\section{References}

1. CONAB Companhia Nacional de Abastecimento. Available online: https://www.conab.gov.br/ (accessed on 27 May 2019).

2. IBGE. Levantamento Sistemático da Produção Agrícola (LSPA)—Estatística da Produção Agrícola. Available online: https://biblioteca.ibge.gov.br/index.php/biblioteca-catalogo?view=detalhes\&id=72415 (accessed on 19 December 2018).

3. Greenpeace Eating Up the Amazon. Available online: https://www.greenpeace.org/usa/research/eating-upthe-amazon/ (accessed on 2 October 2018).

4. Greenpeace Slaughtering the Amazon. Available online: https://www.greenpeace.org/usa/research/ slaughtering-the-amazon/ (accessed on 10 February 2018).

5. Gibbs, H.K.; Munger, J.; L'Roe, J.; Barreto, P.; Pereira, R.; Christie, M.; Amaral, T.; Walker, N.F. Did Ranchers and Slaughterhouses Respond to Zero-Deforestation Agreements in the Brazilian Amazon? Conserv. Lett. 2016, 9, 32-42. [CrossRef]

6. Arima, E.Y.; Barreto, P.; Araújo, E.; Soares-Filho, B. Public policies can reduce tropical deforestation: Lessons and challenges from Brazil. Land Use Policy 2014, 41, 465-473. [CrossRef]

7. Nepstad, D.; McGrath, D.; Stickler, C.; Alencar, A.; Azevedo, A.; Swette, B.; Bezerra, T.; DiGiano, M.; Shimada, J.; Seroa da Motta, R.; et al. Slowing Amazon deforestation through public policy and interventions in beef and soy supply chains. Science 2014, 344, 1118-1123. [CrossRef] [PubMed]

8. Assunção, J.; Rocha, R. Getting Greener by Going Black: The Priority Municipalities in Brazil. Technical Paper. Available online: https://climatepolicyinitiative.org/wp-content/uploads/2014/08/Getting-Greener-byGoing-Black-Technical-Paper.pdf (accessed on 2 October 2018).

9. Moutinho, P.; Guerra, R.; Azevedo-Ramos, C. Achieving zero deforestation in the Brazilian Amazon: What is missing? Elem. Sci. Anthr. 2016, 4, 100125. [CrossRef]

10. Stickler, C.M.; Nepstad, D.C.; Azevedo, A.A.; McGrath, D.G. Defending public interests in private lands: Compliance, costs and potential environmental consequences of the Brazilian Forest Code in Mato Grosso. Philos. Trans. R. Soc. B Biol. Sci. 2013, 368, 20120160. [CrossRef]

11. Fearnside, P.M. Business as Usual: A Resurgence of Deforestation in the Brazilian Amazon. Yale Environ. 2017, 360, 1-6.

12. Soares-filho, B.; Rajão, R.; Macedo, M.; Carneiro, A.; Costa, W.; Coe, M.; Rodrigues, H.; Alencar, A. Cracking Brazil's Forest Code. Science 2014, 344, 363-364. [CrossRef]

13. Strassburg, B.B.N.; Brooks, T.; Feltran-Barbieri, R.; Iribarrem, A.; Crouzeilles, R.; Loyola, R.; Latawiec, A.E.; Oliveira Filho, F.J.B.; De Scaramuzza, C.A.M.; Scarano, F.R.; et al. Moment of truth for the Cerrado hotspot. Nat. Ecol. Evol. 2017, 1. [CrossRef] 
14. Cerrado-Manifesto The Future of the Cerrado in the Hands of the Market: Deforestation and Native Vegetation Conversion Must Be Stopped. Available online: https://d3nehc6yl9qzo4.cloudfront.net/ downloads/cerradomanifesto_september2017_atualizadooutubro.pdf (accessed on 2 October 2018).

15. Assunção, J.; Gandour, C.; Rocha, R. Deforestation slowdown in the Brazilian Amazon: Prices or policies? Environ. Dev. Econ. 2015, 20, 697-722. [CrossRef]

16. Alix-Garcia, J.; Rausch, L.L.; L'Roe, J.; Gibbs, H.K.; Munger, J. Avoided Deforestation Linked to Environmental Registration of Properties in the Brazilian Amazon. Conserv. Lett. 2018, 11, e12414. [CrossRef]

17. Nepstad, D.; Anderson, A.; Dietzsch, L.; Merry, F.; Hissa, L.; Soares-Filho, B.; Bowman, M.; Maretti, C.; Garcia, R.; Moutinho, P.; et al. Role of Brazilian Amazon protected areas in climate change mitigation. Proc. Natl. Acad. Sci. USA 2010, 107, 10821-10826. [CrossRef]

18. Nepstad, D.; Soares-Filho, B.S.; Merry, F.; Lima, A.; Moutinho, P.; Carter, J.; Bowman, M.; Cattaneo, A.; Rodrigues, H.; Schwartzman, S.; et al. The End of Deforestation in the Brazilian Amazon. Science 2009, 326 1350-1351. [CrossRef] [PubMed]

19. Gibbs, H.K.; Rausch, L.; Munger, J.; Schelly, I.; Morton, D.C.; Noojipady, P.; Soares-Filho, B.; Barreto, P.; Micol, L.; Walker, N.F. Brazil's Soy Moratorium. Science 2015, 347, 377-378. [CrossRef] [PubMed]

20. Kastens, J.H.; Brown, J.C.; Coutinho, A.C.; Bishop, C.R.; Esquerdo, J.C.D.M. Soy moratorium impacts on soybean and deforestation dynamics in Mato Grosso, Brazil. PLoS ONE 2017, 12. [CrossRef] [PubMed]

21. Dou, Y.; da Silva, R.F.B.; Yang, H.; Liu, J. Spillover effect offsets the conservation effort in the Amazon. J. Geogr. Sci. 2018, 28, 1715-1732. [CrossRef]

22. Ratter, J.A.; Ribeiro, J.F.; Bridgewater, S. The Brazilian cerrado vegetation and threats to its biodiversity. Ann. Bot. 1997, 80, 223-230. [CrossRef]

23. Sano, E.E.; Rodrigues, A.A.; Martins, E.S.; Bettiol, G.M.; Bustamante, M.M.C.; Bezerra, A.S.; Couto, A.F.; Vasconcelos, V.; Schüler, J.; Bolfe, E.L. Cerrado ecoregions: A spatial framework to assess and prioritize Brazilian savanna environmental diversity for conservation. J. Environ. Manag. 2019, 232, 818-828. [CrossRef]

24. Sano, E.E.; Rosa, R.; Brito, J.L.S.; Ferreira, L.G. Land cover mapping of the tropical savanna region in Brazil. Environ. Monit. Assess. 2010, 166, 113-124. [CrossRef]

25. Arantes, A.E.; Ferreira, L.G.; Coe, M.T. The seasonal carbon and water balances of the Cerrado environment of Brazil: Past, present, and future influences of land cover and land use. ISPRS J. Photogramm. Remote Sens. 2016, 117, 66-78. [CrossRef]

26. Casa Civil Decree 23,793 of 1934-The Brazilian Forest Code. Available online: http://www.planalto.gov.br/ ccivil_03/decreto/1930-1949/D23793impressao.htm (accessed on 3 April 2019).

27. Casa Civil Law 4771 of 1965-The Brazilian Forest Code. Available online: http://www.planalto.gov.br/ ccivil_03/LEIS/L4771impressao.htm (accessed on 3 April 2019).

28. Casa Civil Law 12,651 of 2012-The New Brazilian Forest Code. Available online: http://www.planalto.gov. br/ccivil_03/_ato2011-2014/2012/lei/112651.htm (accessed on 22 May 2019).

29. SFB Sicar-Sistema Nacional de Cadastro Ambiental Rural. Available online: http://www.car.gov.br/\#/ (accessed on 24 May 2019).

30. Azevedo, A.A.; Rajão, R.; Costa, M.A.; Stabile, M.C.C.; Macedo, M.N.; dos Reis, T.N.P.; Alencar, A.; Soares-Filho, B.S.; Pacheco, R. Limits of Brazil's Forest Code as a means to end illegal deforestation. Proc. Natl. Acad. Sci. USA 2017, 114, 7653-7658. [CrossRef]

31. Alix-Garcia, J.; Gibbs, H.K. Forest conservation effects of Brazil's zero deforestation cattle agreements undermined by leakage. Glob. Environ. Change 2017, 47, 201-217. [CrossRef]

32. Klingler, M.; Richards, P.D.; Ossner, R. Cattle vaccination records question the impact of recent zero-deforestation agreements in the Amazon. Reg. Environ. Change 2018, 18, 33-46. [CrossRef]

33. Carvalho, W.D.; Mustin, K.; Hilário, R.R.; Vasconcelos, I.M.; Eilers, V.; Fearnside, P.M. Deforestation control in the Brazilian Amazon: A conservation struggle being lost as agreements and regulations are subverted and bypassed. Perspect. Ecol. Conserv. 2019. [CrossRef]

34. Rudorff, B.F.T.; Adami, M.; Risso, J.; de Aguiar, D.A.; Pires, B.; Amaral, D.; Fabiani, L.; Cecarelli, I. Remote Sensing Images to Detect Soy Plantations in the Amazon Biome-The Soy Moratorium Initiative. Sustainability 2012, 4, 1074-1088. [CrossRef]

35. Massoca, P.; Lui, G. Lessons from the soy and beef moratoria in Brazil. Zero Deforestation Commit. Change 2017, 58, 151-159. 
36. Proforest. Socio-Environmental Monitoring of the Cattle Sector in Brazil. Available online: https://www. proforest.net/en/publications/responsible-sourcing-and-production-briefings/bn09_eng_final_web.pdf (accessed on 10 March 2019).

37. Zu Ermgassen, E.K.H.J.; Ayre, B.; Godar, J.; Bastos Lima, M.G.; Bauch, S.; Garrett, R.; Green, J.; Lathuillière, M.J.; Löfgren, P.; MacFarquhar, C.; et al. Using supply chain data to monitor zero deforestation commitments: An assessment of progress in the Brazilian soy sector. Environ. Res. Lett. 2019. [CrossRef]

38. Mapbiomas Project MapBiomas-Collection 2.3 of Brazilian Land Cover \& Use Map Series. Available online: https://mapbiomas.org/ (accessed on 15 January 2019).

39. MMA Biomas. Available online: http://www.mma.gov.br/biomas (accessed on 13 May 2019).

40. Rudorff, B.; Oliveira, L. Geospatial Analyses of the Annual Crops Dynamic in the Brazilian Cerrado Biome. Available online: https://www.idhsustainabletrade.com/uploaded/2016/04/Geospatial_analyses_of_ the_annual_crops_dynamic_in_the_brazilian_Cerrado_biome.pdf (accessed on 25 April 2019).

41. Arima, E.; Barreto, P.; Brito, M. Pecuária na Amazônia: Tendências e implicações. Available online: https:// imazon.org.br/pecuaria-na-amazonia-tendencias-e-implicacoes-para-a-conservacao-ambiental/ (accessed on 10 December 2018).

42. Brito, B. Potential trajectories of the upcoming forest trading mechanism in Pará State, Brazilian Amazon. PLoS ONE 2017, 12. [CrossRef]

43. Englund, O.; Sparovek, G.; Berndes, G.; Freitas, F.; Ometto, J.P.; Oliveira, P.V.D.C.E.; Costa, C.; Lapola, D. A new high-resolution nationwide aboveground carbon map for Brazil. Geo Geogr. Environ. 2017, 4, e00045. [CrossRef]

44. Reich, P.B.; Luo, Y.; Bradford, J.B.; Poorter, H.; Perry, C.H.; Oleksyn, J. Temperature drives global patterns in forest biomass distribution in leaves, stems, and roots. Proc. Natl. Acad. Sci. USA 2014, 111, 13721-13726. [CrossRef]

45. Spawn, S.A.; Lark, T.J.; Gibbs, H.K. Carbon emissions from cropland expansion in the United States. Environ. Res. Lett. 2019, 14, 045009. [CrossRef]

46. Fick, S.E.; Hijmans, R.J. WorldClim 2: New 1-km spatial resolution climate surfaces for global land areas. Int. J. Clim. 2017, 37, 4302-4315. [CrossRef]

47. Hengl, T.; Mendes de Jesus, J.J.; Heuvelink, G.B.M.; Ruiperez Gonzalez, M.; Kilibarda, M.; Blagotić, A.; Shangguan, W.; Wright, M.N.; Geng, X.; Bauer-Marschallinger, B.; et al. SoilGrids250m: Global gridded soil information based on machine learning. PLoS ONE 2017, 12, e0169748. [CrossRef] [PubMed]

48. Don, A.; Schumacher, J.; Freibauer, A. Impact of tropical land-use change on soil organic carbon stocks-A meta-analysis. Glob. Change Biol. 2011, 17, 1658-1670. [CrossRef]

49. IUCN. The IUCN Red List of Threatened Species. 2018. Available online: https://www.iucnredlist.org/ (accessed on 17 May 2019).

50. Rondinini, C.; di Marco, M.; Chiozza, F.; Santulli, G.; Baisero, D.; Visconti, P.; Hoffmann, M.; Schipper, J.; Stuart, S.N.; Tognelli, M.F.; et al. Global habitat suitability models of terrestrial mammals. Philos. Trans. R. Soc. B Biol. Sci. 2011, 366, 2633-2641. [CrossRef]

51. Birdlife BirdLife | Partnership for Nature and People. Available online: http://www.birdlife.org/ (accessed on 18 December 2019).

52. Wilcove, D.S.; Wikelski, M. Going, Going, Gone: Is Animal Migration Disappearing. PLoS Biol. 2008, 6, e188. [CrossRef]

53. Thomas, C.D.A.C.; Green, R.E.; Bakkenes, M.; Beaumont, L.J.; Clooingham, Y.C.; Erasmus, B.F.N.; De Siquieira, M.F.; Grainger, A.; Hannah, L.; Hughes, L.; et al. Extinction risk from climate change. Nature 2004, 427, 145-148. [CrossRef] [PubMed]

54. IBGE. Mapa de Biomas e de Vegetação. Available online: https://ww2.ibge.gov.br/home/presidencia/noticias/ 21052004biomashtml.shtm (accessed on 17 May 2019).

55. Lockwood, T. Integrating design into organizational culture. Des. Manag. Rev. 2010, 15, 32-39. [CrossRef]

56. Iwamura, T.; Possingham, H.P.; Chadès, I.; Minton, C.; Murray, N.J.; Rogers, D.I.; Treml, E.A.; Fuller, R.A. Migratory connectivity magnifies the consequences of habitat loss from sea-level rise for shorebird populations. Tohoku J. Exp. Med. 2013, 230. [CrossRef]

57. De Azevedo, T.R.; Junior, C.C.; Junior, A.B.; dos Santos Cremer, M.; Piatto, M.; Tsai, D.S.; Barreto, P.; Martins, H.; Sales, M.; Galuchi, T.; et al. SEEG initiative estimates of Brazilian greenhouse gas emissions from 1970 to 2015. Sci. Data 2018, 5, 180045. [CrossRef] 
58. Martini, D.Z.; Moreira, M.A.; Cruz de Aragão, L.E.O.E.; Formaggio, A.R.; Dalla-Nora, E.L. Potential land availability for agricultural expansion in the Brazilian Amazon. Land Use Policy 2015, 49, 35-42. [CrossRef]

59. Soterroni, A.C.; Mosnier, A.; Carvalho, A.X.Y.; Câmara, G.; Obersteiner, M.; Andrade, P.R.; Souza, R.C.; Brock, R.; Pirker, J.; Kraxner, F.; et al. Future environmental and agricultural impacts of Brazil's Forest Code. Environ. Res. Lett. 2018, 13, 074021. [CrossRef]

60. Soares-Filho, B.; Rajão, R.; Merry, F.; Rodrigues, H.; Davis, J.; Lima, L.; Macedo, M.; Coe, M.; Carneiro, A.; Santiago, L. Brazil's Market for Trading Forest Certificates. PLoS ONE 2016, 11, e0152311. [CrossRef] [PubMed]

61. Rajão, R.; Moutinho, P.; Soares, L. The Rights and Wrongs of Brazil's Forest Monitoring Systems. Conserv. Lett. 2017, 10, 495-496. [CrossRef]

62. Arima, E.; VanWey, L.; Richards, P.; Bhattarai, N.; Cohn, A. Are Brazil's Deforesters Avoiding Detection? Conserv. Lett. 2016, 10, 470-476. [CrossRef]

63. L'Roe, J.; Rausch, L.; Munger, J.; Gibbs, H.K. Mapping properties to monitor forests: Landholder response to a large environmental registration program in the Brazilian Amazon. Land Use Policy 2016, 57, 193-203. [CrossRef]

64. Meijer, K.S. A comparative analysis of the effectiveness of four supply chain initiatives to reduce deforestation. Trop. Conserv. Sci. 2015, 8, 583-597. [CrossRef]

65. Meijer, K. Can Supply Chain Initiatives Reduce Deforestation? A Comparative Analysis of Cases from Brazil and Indonesia; Deutsches Institut für Entwicklungspolitik: Bonn, Germany, 2014; ISBN 9783889856623.

66. Svahn, J.; Brunner, D. Did the Soy Moratorium Reduce Deforestation in the Brazilian Amazon? Master's Thesis, Norwegian School of Economics, Bergen, Norway, 2018.

67. Rausch, L.L.; Gibbs, H.K.; Schelly, I.; Brandão, A.; Morton, D.C.; Filho, A.C.; Strassburg, B.; Walker, N.; Noojipady, P.; Barreto, P.; et al. Soy expansion in Brazil's Cerrado. Conserv. Lett. 2019, 12. [CrossRef]

68. Soterroni, A.C.; Ramos, F.M.; Mosnier, A.; Fargione, J.; Andrade, P.R.; Baumgarten, L.; Pirker, J.; Obersteiner, M.; Kraxner, F.; Câmara, G.; et al. Expanding the Soy Moratorium to Brazil's Cerrado. Sci. Adv. 2019, 5, eaav7336. [CrossRef]

69. Nepstad, D.C.; Stickler, C.M.; Almeida, O.T. Globalization of the Amazon soy and beef industries: Opportunities for conservation. Conserv. Biol. 2006, 20, 1595-1603. [CrossRef]

70. Curtis, P.G.; Slay, C.M.; Harris, N.L.; Tyukavina, A.; Hansen, M.C. Classifying drivers of global forest loss. Science 2018, 361, 1108-1111. [CrossRef]

71. Margulis, S. Causes of Deforestation of the Brazilian Amazon; World Bank Working Papers; The World Bank: New York, NY, USA, 2003; ISBN 978-0-8213-5691-3.

72. Koyuncu, C.; Yilmaz, R. Deforestation, corruption, and private ownership in the forest sector. Qual. Quant. 2013, 47, 227-236. [CrossRef]

73. Reydon, B.P.; Fernandes, V.B.; Telles, T.S. Land governance as a precondition for decreasing deforestation in the Brazilian Amazon. Land Use Policy 2019, 104313. [CrossRef]

74. Ferreira, J.; Peres, C.A.; Pompeu, P.S.; Tabarelli, M.; Barlow, J.; Pardini, R.; Gardner, T.A.; Lima, A.; Louzada, J.; Berenguer, E.; et al. Brazil's environmental leadership at risk. Science 2014, 346, 706-707. [CrossRef] [PubMed]

75. Loyola, R. Brazil cannot risk its environmental leadership. Divers. Distrib. 2014, 20, 1365-1367. [CrossRef]

76. Fearnside, P.M. Brazilian politics threaten environmental policies. Science 2016, 353, 746-748. [CrossRef] [PubMed]

77. Azevedo-Santos, V.M.; Fearnside, P.M.; Oliveira, C.S.; Padial, A.A.; Pelicice, F.M.; Lima, D.P.; Simberloff, D.; Lovejoy, T.E.; Magalhães, A.L.B.; Orsi, M.L.; et al. Removing the abyss between conservation science and policy decisions in Brazil. Biodivers. Conserv. 2017, 26, 1745-1752. [CrossRef]

78. Alves, G.H.Z.; Tófoli, R.M.; Rodrigues-Filho, J.L.; Sacramento, P.A.; Cionek, V.M.; Figueiredo, B.R.S.; do Couto, E.V. Brazil's vegetation ravage may be encouraged by law. Biodivers. Conserv. 2020, 8-10. [CrossRef]

79. Bragagnolo, C.; Carvalho Lemos, C.; Ladle, R.J.; Pellin, A. Streamlining or sidestepping? Political pressure to revise environmental licensing and EIA in Brazil. Environ. Impact Assess. Rev. 2017, 65, 86-90. [CrossRef]

80. Vieira, R.R.S.; Ribeiro, B.R.; Resende, F.M.; Brum, F.T.; Machado, N.; Sales, L.P.; Macedo, L.; Soares-Filho, B.; Loyola, R. Compliance to Brazil's Forest Code will not protect biodiversity and ecosystem services. Divers. Distrib. 2018, 24, 434-438. [CrossRef]

81. Valentim, S.S. Projeto de Lei $n^{\circ}$ 5051, de 2019; Senado Federal Brasileir: Brasília, Brazil, 2019; pp. 1-7. 
82. Chiaretti, D. Projeto Põe em Risco Vegetação Nativa de “Três Bahias”. Available online: https://valor.globo.com/ brasil/coluna/projeto-poe-em-risco-vegetacao-nativa-de-tres-bahias.ghtml (accessed on 21 January 2020).

83. MAPA. Projeções do Agronegócio: Brasil 2017/18 a 2027/28 Projeções de Longo Prazo; MAPA: Brasília, Brasil, 2018; ISBN 9788579911163.

84. IBGE. Pesquisa da Pecuária Municipal (PPM). Available online: https://www.ibge.gov.br/estatisticasnovoportal/economicas/agricultura-e-pecuaria/9107-producao-da-pecuaria-municipal.html?=\&t=serieshistoricas (accessed on 10 March 2019).

85. Arantes, A.E.; Couto, V.R.; Sano, E.E.; Ferreira, L.G. Livestock intensification potential in Brazil based on agricultural census and satellite data analysis. Pesqui. Agropecuária Bras. 2018, 53, 1053-1060. [CrossRef]

86. Zu Ermgassen, E.; Alcântara, M.; Balmford, A.; Barioni, L.; Neto, F.; Bettarello, M.; Brito, G.; Carrero, G.; Florence, E.; Garcia, E.; et al. Results from On-The-Ground Efforts to Promote Sustainable Cattle Ranching in the Brazilian Amazon. Sustainability 2018, 10, 1301. [CrossRef]

87. Garcia, E.; Filho, F.S.V.R.; Mallmann, G.M.; Fonseca, F. Costs, benefits and challenges of sustainable livestock intensification in a major deforestation frontier in the Brazilian amazon. Sustainability 2017, 9. [CrossRef]

88. Strassburg, B.B.N.; Latawiec, A.E.; Barioni, L.G.; Nobre, C.A.; da Silva, V.P.; Valentim, J.F.; Vianna, M.; Assad, E.D. When enough should be enough: Improving the use of current agricultural lands could meet production demands and spare natural habitats in Brazil. Glob. Environ. Change 2014, 28, 84-97. [CrossRef]

89. Soto-Navarro, C.; Ravilious, C.; Arnell, A.; de Lamo, X.; Harfoot, M.; Hill, S.L.L.; Wearn, O.R.; Santoro, M.; Bouvet, A.; Mermoz, S.; et al. Mapping co-benefits for carbon storage and biodiversity to inform conservation policy and action. Philos. Trans. R. Soc. B Biol. Sci. 2020, 375, 20190128. [CrossRef] [PubMed]

90. Embrapa TerraClass 2004 a 2014-Avaliação da Dinâmica do Uso e Cobertura da Terra no Período de 10 Anos nas Áreas Desflorestadas da Amazônia Legal Brasileira. Available online: www.inpe.br/era/projetos_ pesquisas/dados_terraclass.php (accessed on 25 May 2019).

91. MMA. Mapeamento do Uso e Cobertura do Cerrado: Projeto TerraClass Cerrado 2013. In Mapeamento do Uso e Cobertura do Cerrado Projeto TerraClass Cerrado 2013; MMA: Brasília, Brasil, 2013.

92. INPE Instituto Nacional De Pesquisas Espaciais. Prodes-Programa de Monitoramento da Floresta Amazonica Brasileira por Satelite. Available online: http://www.obt.inpe.br/OBT/assuntos/programas/ amazonia/prodes (accessed on 10 October 2018).

93. INPE Instituto Nacional De Pesquisas Espaciais. Incremento Anual de Área Desmatada no Cerrado Brasileiro. Available online: http://cerrado.obt.inpe.br/ (accessed on 10 October 2018).

94. ICMBio Instituto Chico Mendes de Conservação da Biodiversidade. Available online: http://www.icmbio. gov.br/portal/ (accessed on 24 January 2020).

95. FUNAI Fundação Nacional do Índio. Available online: http://www.funai.gov.br/ (accessed on 24 January 2020).

96. IUCN. Habitats Classification Scheme. Available online: http://s3.amazonaws.com/iucnredlist-newcms/ staging/public/attachments/3125/dec_2012_guidance_habitats_classification_scheme.pdf (accessed on 10 February 2019).

97. IBGE. Manual Técnico de Uso da Terra-3a Edição. Available online: https://biblioteca.ibge.gov.br/ visualizacao/livros/liv81615.pdf (accessed on 10 February 2019).

(C) 2020 by the authors. Licensee MDPI, Basel, Switzerland. This article is an open access article distributed under the terms and conditions of the Creative Commons Attribution (CC BY) license (http://creativecommons.org/licenses/by/4.0/). 